\title{
NOVITATES GABONENSES 65. A NEW RARE ENDEMIC AMPHIBLEMMA (MELASTOMATACEAE) FROM MVE LAKENE, GABON
}

\author{
MIGUEL E. LEAL \\ Missouri Botanical Garden, P.O. Box 299, St. Louis, Missouri 63166, USA \\ e-mail: Miguel.Leal@mobot.org
}

\begin{abstract}
SUMMARY
A new species of Amphiblemma from the Mvé Lakéné Plateau, Monts de Cristal is described.

Key words: Amphiblemma, Melastomataceae, Africa, taxonomy, Gabon.

In March 2006, during a biodiversity assessment on the Mvé Lakéné Plateau, in between the national parks of Mont Sené and Mbe in the Monts de Cristal, on the highest peak of the plateau a new species of Amphiblemma was discovered. It resembles A. heterophyllum Jacq.-Fél. in its leaf characteristics and A. hallei Jacq.-Fél. (Jacques-Félix 1983 ) in its capsule characteristics. The new species has a herbaceous habit and its capsule is strongly ribbed.
\end{abstract}

Amphiblemma mvensis M.E. Leal, spec. nov. - Fig. 1

Haec species ab A. heterophyllum Jacq.-Fél. differt habitu herbaceo est et capsula eia costata valde subglabraque. - Typus: M.E. Leal 984 (holo MO; iso LBV, WAG), Gabon, Monts de Cristal, 24 March 2006.

Small herb, 4-7 cm high, epiphytic and terrestrial; branches glabrous and rounded. Leaf petiole $0.5-2 \mathrm{~cm}$. Lamina ovate-cordate, $2.5-6$ by $1.1-2.4 \mathrm{~cm}$, margin serrate ending in ciliate red hairs $0.5 \mathrm{~cm}$ long, apex acute, three main veins, above and below sparsely ciliate with $0.5 \mathrm{~cm}$ long slender purple hairs, below whitish green. Inflorescence a terminal monopodial cyme, sessile, with 2 or 3 sessile flowers. Hypanthium $1.5-2 \mathrm{~mm}$ long, near glabrous with a few ciliate purple hairs. Calyx lobes $1.5-2$ by $0.1-0.3 \mathrm{~mm}$, triangular with a truncate apex. Petals $4-5$ by $3-4 \mathrm{~mm}$, pink. Anthers $1 \mathrm{~mm}$ long. Style 1-2 mm long, stigma capitate. Capsule $4-5$ by $4-6 \mathrm{~mm}$, truncate with five prominent ribs and nearly glabrous; rim 5-lobed. Seeds $0.5 \mathrm{~mm}$ in diameter.

Distribution - Gabon, Monts de Cristal, highest peak of Mvé Lakéné Plateau, $0^{\circ} 36^{\prime} 0^{\prime \prime} \mathrm{N}, 10^{\circ} 10^{\prime} 50^{\prime \prime} \mathrm{E}$.

Habitat - Terrestrial on rocky forest floor and epiphytic on trunks of semi-elfin cloud forest at an altitude of $800 \mathrm{~m}$. 


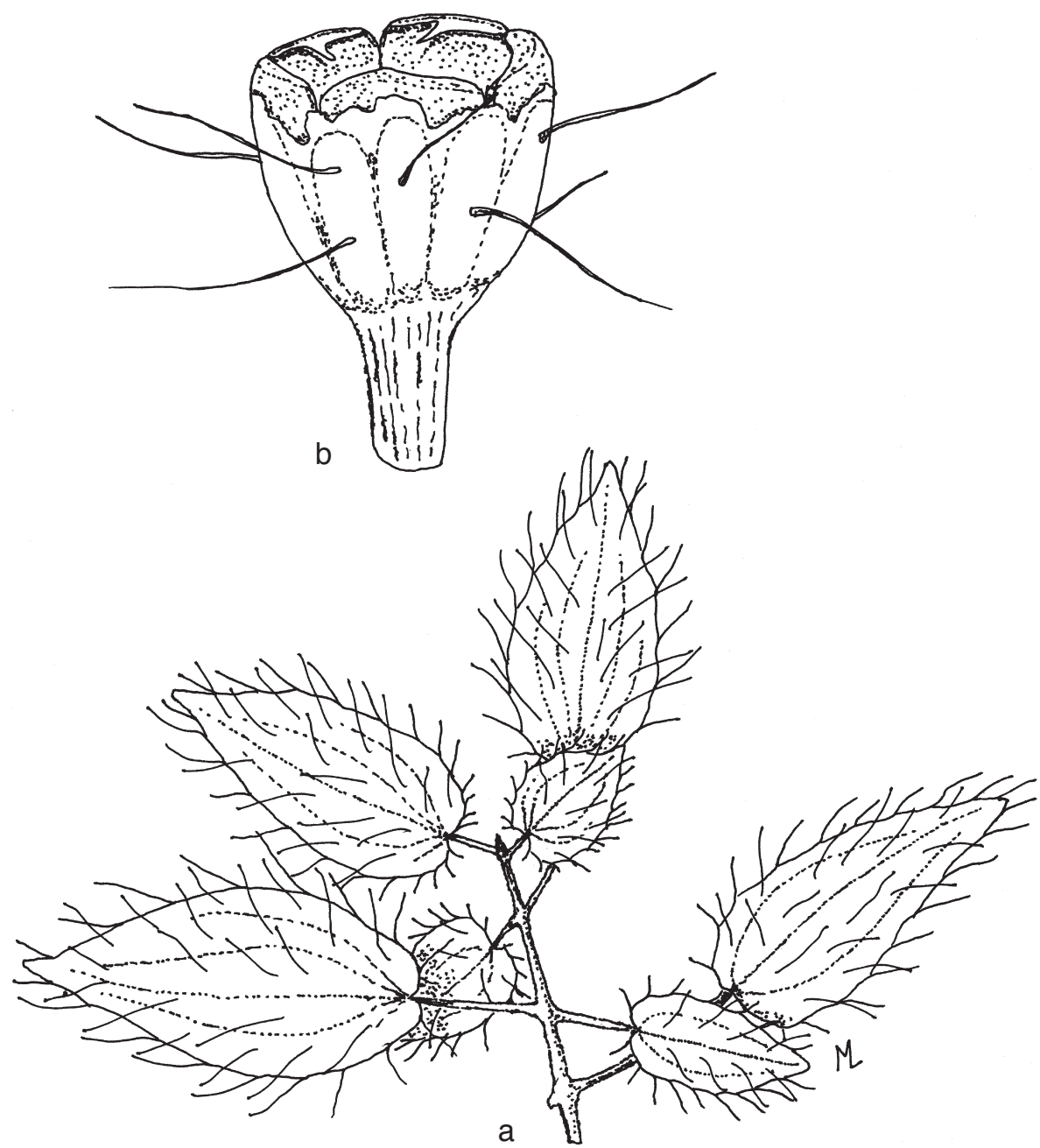

Fig. 1. Amphiblemma mvensis M.E. Leal. a. Habit; b. capsule (Leal 984, LBV, MO, WAG).

Notes - This new Amphiblemma species and other sister species like A. heterophyllum and A. letouzeyi are very rare and considered critically endangered by IUCN criteria (IUCN 2001). The latter species is only known from one locality (Nkoltsia) in Cameroon and three specimens (Letouzey 12705, Villiers 778, 826) and the former species from one locality (Méla) and one specimen (Hallé \& Villiers 5195).

This new species is also only known from one isolated hilltop and represented by a small population. Its rare occurrence makes it vulnerable for any form of logging and mining on and around the plateau. The peak itself is not likely to be exploited because of its inaccessibility but clearing the forest around the plateau can cause the forest on hilltops to disappear by a human induced change in climate as simulations predict for Gabon (Baidya Roy et al. 2005). 
The Monts de Cristal are famous for their botanical richness and the discovery of this new species of Amphiblemma illustrates this once more. This first expedition onto the plateau also shows that there is still much to be discovered in the Monts de Cristal even after decades of botanical activities. Remote and difficult to access locations in particular remain unexplored and on the way up onto the plateau the formerly endemic tree species from Cameroon, Korupodendron songweanum Litt \& Cheek (Vochysiaceae) was encountered, and further on the plateau the recently discovered Calvoa maculata M.E. Leal (Melastomataceae) (Leal 2005).

\section{ACKNOWLEDGEMENTS}

Fieldwork was funded by the National Geographical Society (NGS) and the Central Africa Regional Program of the Environment (CARPE) in collaboration with Wildlife Conservation Society (WCS). A special 'remerciement' goes to the National Herbarium of Gabon (HNG).

\section{REFERENCES}

Baidya Roy, S., P.D. Walsh \& J.W. Lichtstein. 2005. Can logging in equatorial Africa affect adjacent parks? Ecology and Society 10: 6-17.

Jacques-Félix, H. 1983. Mélastomatacées. Flore du Gabon 25: 75-91.

IUCN Red List Categories and Criteria version 3.1. 2001. http://www.iucn.org/themes/ssc/redlists/ RLcats2001booklet.html.

Leal, M.E. 2005. Novitates Gabonenses 61. a new rare endemic Calvoa (Melastomataceae) from Mbe National Park, Gabon. Blumea 50: 473-475. 